\title{
DESIGN OF A PACKED-BED ABSORPTION COLUMN CONSIDERING FOUR PACKING TYPES AND APPLYING MATLAB
}

\section{DISEÑO DE UNA COLUMNA DE ABSORCIÓN EMPACADA CONSIDERANDO CUATRO TIPOS DE EMPAQUE Y APLICANDO MATLAB}

\author{
A. Pérez Sánchez ${ }^{1 *}$ E. J. Pérez Sánchez ${ }^{2}$ y R. Segura Silva ${ }^{3}$ \\ ${ }^{1}$ Universidad de Camagüey. Facultad de Ciencias Aplicadas a la Industria. Camagüey, Cuba \\ ${ }^{2}$ Empresa Industrial Ceballos. Departamento de Producción. Ciego de Ávila, Cuba \\ 3 Centro de Ingeniería Genética y Biotecnología de Camagüey. Departamento de Documentación. \\ Camagüey, Cuba. \\ *amauryps@nauta.cu
}

(recibido/received: 12-Julio-2016; aceptado/accepted: 12-Septiembre-2016)

\begin{abstract}
In the present work, a packed bed absorption column is designed to recover certain amounts of ethanol contained in a gaseous stream. Four packing types $\left(50-\mathrm{mm}\right.$ metal Hiflow ${ }^{\circledR}$ rings, 50 -mm ceramic Pall ${ }^{\circledR}$ rings, 50-mm metal Top $P a k^{\circledR}$ rings and 25-mm metal $V S P^{\circledR}$ rings) are considered in order to select the most appropriate one in terms of column dimensions, pressure drop and mass-transfer results. Several design parameters were determined including column diameter $(D)$, packing height $(Z)$, overall masstransfer coefficient $\left(K_{m}\right)$ and gas pressure drop $(\Delta P / Z)$, as well as the overall number of gas-phase transfer units $\left(N_{t O G}\right)$, overall height of a gas-phase transfer unit $\left(H_{t O G}\right)$ and the effective surface area of packing $\left(a_{\mathrm{h}}\right)$. The most adequate packing to use for this absorption system constitutes the $25-\mathrm{mm}$ metal $V S P^{\circledast}$ rings, since it provided the greatest values of $K_{m}\left(0.325 \mathrm{kmol} / \mathrm{m}^{3} . \mathrm{s}\right)$, and $a_{h}\left(169.57 \mathrm{~m}^{-1}\right)$, as well as the lowest values of both $\mathrm{Z}(0.6 \mathrm{~m})$ and $\mathrm{H}_{\mathrm{tOG}}(0.145 \mathrm{~m})$, meaning that it will supply the higher masstransfer conditions with the lowest column dimensions. The influence of both gas mixture $\left(Q_{G}\right)$ and solvent $\left(m_{L}\right)$ feed flowrates on $D, Z, K_{m}, \triangle P / Z, N_{t O G}$ and $H_{t O G}$ was also evaluated for the four packing considered. The design methodology was solved using computing software $M A T L A B^{\circledR}$ version 7.8.0.347 (R2009a) (Math Works, 2009), and also Microsoft Excel ${ }^{\circledR}$.
\end{abstract}

Keywords: Packed absorber, design, packing, simulation, MATLAB.

\section{RESUMEN}

En el presente trabajo se diseña una columna de absorción empacada para recuperar ciertas cantidades de etanol contenido en una corriente gaseosa. Se consideran 4 tipos de empaques (anillos Hiflow ${ }^{\circledR}$ metálicos de $50 \mathrm{~mm}$, anillos $P_{a l l^{\circledR}}$ cerámicos de $50 \mathrm{~mm}$, anillos Top $P a k^{\circledR}$ metálicos de $50 \mathrm{~mm}, \mathrm{y}$ anillos $V S P^{\circledR}$ metálicos de $25 \mathrm{~mm}$ ) con el fin de seleccionar el más apropiado en términos de dimensiones de la columna, caída de presión y resultados de transferencia de masa. Se determinaron varios parámetros de diseño incluyendo diámetro de la columna $(D)$, altura del empaque $(Z)$, coeficiente global de transferencia de masa $\left(K_{m}\right)$ y caída de presión gaseosa $(P / Z)$, así como también el número total de unidades de transferencia den fase gaseosa $\left(N_{t O G}\right)$, altura total de unidades de transferencia en fase gaseosa $\left(H_{t O G}\right)$ y el área superficial efectiva del empaque $\left(a_{\mathrm{h}}\right)$. El empaque más 
adecuado de usar en este sistema de absorción constituye los anillos $V S P^{\circledR}$ metálicos de $25 \mathrm{~mm}$, ya que suministra los mayores valores de $K_{m}\left(0.325 \mathrm{kmol} / \mathrm{m}^{3} . \mathrm{s}\right)$, y $a_{h}\left(169.57 \mathrm{~m}^{-1}\right)$, así como también los menores valores de tanto $\mathrm{Z}(0.6 \mathrm{~m})$ y $\mathrm{H}_{\mathrm{tOG}}(0.145 \mathrm{~m})$, significando que suministrará las condiciones más altas de transferencia de masa con las menores dimensiones dela columna. La influencia de los caudales de alimentación de tanto la mezcla gaseosa $\left(Q_{G}\right)$ y el solvente $\left(m_{L}\right)$ sobre $D, Z, K_{m}, \Delta P / Z, N_{t O G}$ y $H_{t O G}$ fue también evaluada para los cuatro tipos de empaques considerados. La metodología de diseño fue resuelta empleando el software $M A T L A B^{\circledR}$ versión 7.8.0.347 (R2009a) (Math Works, 2009), y también Microsoft Excel ${ }^{\circledR}$.

Palabras claves: Absorbedor empacado, diseño, empaque, simulación, MATLAB.

\section{NOMENCLATURE}

$\begin{array}{lll}a & \text { Mass-transfer surface area per unit volume } & \mathrm{m}^{-1} \\ a_{\mathrm{h}} & \text { Effective specific surface area of packing } & \mathrm{m}^{-1}\end{array}$

A Absorption factor

$\mathrm{m}^{-1}$

Ch Hydraulic factor

Dimensionless

$\mathrm{C}_{\mathrm{L}} \quad$ Mass-transfer factor

Dimensionless

$\mathrm{C}_{\mathrm{P}} \quad$ Hydraulic factor

Dimensionless

$\mathrm{C}_{\text {Sflood }} \quad \mathrm{C}_{\mathrm{S}}$ coefficient at flooding conditions $\mathrm{m} / \mathrm{s}$

Dimensionless

$\mathrm{C}_{\mathrm{V}} \quad$ Mass-transfer factor

Dimensionless

$\mathrm{d}_{\mathrm{P}} \quad$ Effective particle diameter

D Tower diameter

$\mathrm{D}_{\mathrm{G}} \quad$ Gas-phase diffusion coefficient

$\mathrm{m}$

$\mathrm{m}$

$\mathrm{D}_{\mathrm{L}}$

Liquid-phase diffusion coefficient

$\mathrm{m}^{2} / \mathrm{s}$

e/k Lennard-Jones parameter

$\mathrm{f}_{\text {flood }} \quad$ Flooding factor

Fp Packing factor

Fr Froude number

$\begin{array}{ll}\mathrm{G} & \text { Mass velocity } \\ \mathrm{G}_{\mathrm{My}} & \text { Gas molar velocity }\end{array}$

$\mathrm{G}_{\mathrm{Mx}} \quad$ Liquid molar velocity

$\mathrm{h}_{\mathrm{L}} \quad$ Liquid holdup

$\mathrm{H} \quad$ Henry's constant

$\mathrm{H}_{\mathrm{tOG}} \quad$ Overall height of a gas-phase transfer unit

$\mathrm{k}_{\mathrm{G}} \quad$ Gas-phase convective mass-transfer coefficient

$\mathrm{k}_{\mathrm{L}} \quad$ Liquid-phase convective mass-transfer coefficient

$\mathrm{K}_{\mathrm{m}} \quad$ Overall volumetric mass-transfer coefficient

$\mathrm{K}_{\mathrm{v}} \quad$ Volumetric mass-transfer coefficient

$\mathrm{K}_{\mathrm{W}} \quad$ Wall factor

m Mass flowrate

M Molecular weight

n Factor

N Molar flowrate

$\mathrm{N}_{\mathrm{tOG}} \quad$ Overall number of gas-phase transfer units

$\Delta \mathrm{P}_{\text {limit }} / \mathrm{Z} \quad$ Maximum pressure drop permitted

$\mathrm{m}^{2} / \mathrm{s}$

$\mathrm{K}$

$\%$

$\mathrm{ft}^{-1}$

Dimensionless

$\mathrm{kg} / \mathrm{m}^{2} . \mathrm{s}$

$\mathrm{kmol} / \mathrm{m}^{2} . \mathrm{s}$

$\mathrm{kmol} / \mathrm{m}^{2} . \mathrm{s}$

Dimensionless

atm

$\mathrm{m}$

$\mathrm{kmol} / \mathrm{m}^{2} . \mathrm{s}$

$\mathrm{m} / \mathrm{s}$

$\mathrm{kmol} / \mathrm{m}^{3} \cdot \mathrm{s}$

$\mathrm{kmol} / \mathrm{m}^{3} . \mathrm{s}$

Dimensionless

$\mathrm{kg} / \mathrm{h}$

$\mathrm{kg} / \mathrm{kmol}$

Dimensionless

$\mathrm{kmol} / \mathrm{h}$

Dimensionless

$\Delta \mathrm{P}_{0} / \mathrm{Z} \quad$ Dry pressure drop

$\mathrm{Pa} / \mathrm{m}$

$\mathrm{Pa} / \mathrm{m}$

Overall pressure drop

$\mathrm{Pa} / \mathrm{m}$

Pressure

atm

$\mathrm{P}$

Volumetric flowrate

$\mathrm{m}^{3} / \mathrm{h}$

$\begin{array}{ll}\mathrm{R} & \text { Ideal gas constant } \\ \% \mathrm{R} & \text { Removal percent }\end{array}$

$\mathrm{m}^{3} \cdot \mathrm{atm} / \mathrm{kmol} \cdot \mathrm{K}$

$\%$

$\mathrm{Re} \quad$ Reynolds number

Dimensionless 


$\begin{array}{lll}\mathrm{Sc} & \text { Schmidt number } & \text { Dimensionless } \\ \mathrm{T} & \text { Temperature } & { }^{\circ} \mathrm{C} \\ \mathrm{T}^{*} & \text { Factor } & \text { Dimensionless } \\ v & \text { Velocity } & \mathrm{m} / \mathrm{s} \\ v_{\text {flood }} & \text { Velocity at flooding conditions } & \mathrm{m} / \mathrm{s} \\ \mathrm{V} & \text { Molar volume } & \mathrm{cm}^{3} / \mathrm{mol} \\ \mathrm{X} & \text { Flow parameter } & \text { Dimensionless } \\ \mathrm{X} & \text { Mole fraction in liquid phase } & \text { Fraction } \\ \mathrm{y} & \text { Mole fraction in gas phase } & \text { Fraction } \\ \mathrm{y}^{*} & \text { Mole fraction in gas phase in equilibrium with the liquid } & \text { Fraction } \\ \mathrm{Z} & \text { Parking height } & \mathrm{m} \\ & & \\ \rho & \text { Density } & \mathrm{kg} / \mathrm{m}^{3} \\ \mu & \text { Viscosity } & \text { Pa.s } \\ \sigma & \text { Collision diameter } & \AA \\ \sigma_{\mathrm{AB}} & \text { Average collision diameter } & \AA \\ \psi_{0} & \text { Dry-packing resistance coefficient } & \AA \\ \varepsilon & \text { Packing porosity or void fraction } & \text { Dimensionless } \\ \Omega_{\mathrm{D}} & \text { Diffusion collision integral } & \text { Dimensionless } \\ \phi & \text { Distribution coefficient } & \text { Dimensionless } \\ (\text { abs }) & \text { Absorbed } & \text { Dimensionless } \\ \mathrm{CO} 2 & \text { Carbon dioxide } & \\ \mathrm{e} & \text { Ethanol } & \\ \mathrm{G} & \text { Gas-phase / Gaseous } & \\ \mathrm{L} & \text { Liquid-phase / Liquid } & \\ \mathrm{W} & \text { Water } & \\ (1) & \text { Bottom of column } & \\ (2) & \text { Top of column } & \\ & & \end{array}$

\section{INTRODUCTION}

Gas-liquid operations are used extensively in chemical and petrochemical industries for transferring mass, heat and momentum between the phases. Among the most important gas-liquid systems employed nowadays is absorption, defined as a mass transfer operation at which one or more soluble components contained in a gas phase mixture are dissolved into a liquid solvent whose volatility is low under process conditions. The absorption process could be classified as physical or chemical. The physical absorption occurs when the target solute is dissolved into the solvent, while the chemical absorption takes place when the target solute reacts with the solvent. The removal efficiency of any physical absorption process will depend on the physical-chemical properties (density, viscosity, diffusivity, etc.) and feed flowrates of the gaseous and liquid streams; the type of mass-transfer contact surface (packing or plate); the operating temperature and pressure (commonly, lower temperatures will favor gas absorption by the liquid solvent); gas-liquid ratio; contact time between phases; and the solute concentration at the inlet gas stream. Gas-liquid absorption operations are usually accomplished in equipment named absorbers.

Absorbers are used to a great extent in industrial complexes and plants to separate and purify gaseous streams, to recover valuable products and chemicals, as well as for contamination control. The most common absorber types employed in industry are plate columns, packed towers, Venturi cleaning towers and spray chambers. Packed towers are widely used for gas-liquid absorption operations and, to a limited extent, for distillations (Perry and Chilton, 2008). A typical packed column consists of a vertical, cylindrical shell containing a support plate for the packing material, mist eliminators, as well 
as a liquid distributing device designed to provide effective irrigation to the packing (Benitez, 2009) (Figure 1). The liquid is fed at the top of the column and trickles down through the packed bed, exposing a large surface to contact the gaseous stream, which is supplied at the bottom of the tower (Ludwig, 1997) (Richardson and Harker, 2002). The tower packing, or fill, should provide a large interfacial surface between liquid and gas per unit volume of packed space, and also should have desirable hydrodynamic/hydraulic characteristics (Benitez, 2009).

Packed-bed absorbers have been widely studied, analyzed and assessed in recent years either to design or evaluate a unit for a given application (Benitez, 2009) (Brunazzi et al., 2002) (Coker, 1991) (Kleine, 1998) (Leye and Froment, 1986) (McNutly and Chopey 1994) (Mohamadbigy et al., 2005) (Siegler, 2003) (Strigle, 1987); to determine mass-transfer coefficients and determine pressure drop in packed beds (Arwikar, 1981) (Bravo and Fair, 1982) (Fair and Bravo, 1987) (Lockett, 1998) (Shulman and Margolis, 2004) (Wagner et al., 1997); for modeling and optimization of absorption operations and equipment (Olutoye and Mohammed, 2006) (Rahbar and Kaghazchi, 2005); and is a frequent topic usually covered in the most important chemical engineering handbooks and mass-transfer related literature (Asano, 2006) (Ludwig, 1997) (Marcilla, 1999) (Pavlov et al., 1981) (Perry and Chilton, 2008) (Peters and Timmerhaus, 1991) (Billet and Schultes, 1995) (Richardson and Harker, 2002) (Treybal, 1980) available nowadays.

The design approach of a packed-bed absorber usually involves the determination of geometrical parameters such as tower diameter (D) and packing height $(\mathrm{Z})$, as well as some other mass-transfer and operational variables such as convective mass-transfer coefficients for gas and liquid streams; dry and overall pressure drops; as well as overall mass-transfer coefficient. A well designed packed-bed tower will provide the required mass-transfer contact between gas and liquid phases, with low pressure drop, small capital and operating costs, and high removal efficiencies.

The use of simulation and modeling techniques to design, evaluate or optimize chemical processes, equipment and unit operations, either from the economic or technical point of view, have reached unprecedented levels in recent years (Boyadjiev, 2010) (Dimian and Bildea, 2008) (Finlayson, (2006). Among the most developed and common computer applications used today is the MATLAB ${ }^{\circledR}$ software (Math Works, 2009), since it provides numerical methods which permit to solve numerous mathematical, statistical, financial, trigonometric, etc. functions by using special application fields referred to as toolboxes (Karris, 2004) (Nakamura, 2002). MATLAB ${ }^{\circledR}$ software is considered a highlevel software package with many built-in functions, which is very easy to use, even for people without prior programming experience, and that make the learning of numerical and mathematical methods much easier and more interesting (Karris, 2004) (Yang et al., 2005).

Several authors have used $M A T L A B^{\circledR}$ software to carry out the simulation of chemical processes operations and equipment, the evaluation of alternatives and base cases, as well as the optimization of existing units or plants. For example, Mušič and Matko (Mušič and Matko, 1998) used Petri nets and Sequential Function Charts (SFC) methods for modelling batch recipes on a combined discrete/continuous support, applying a simulation environment based on MATLAB/Simulink ${ }^{\circledR}$ tolls. Kukurugya and Terpák (Kukurugya and Terpák, 2006) developed different approaches using $M A T L A B^{\circledR}$ simulation tools, for modelling of equipment installed in the raw materials processing area both at coal and limestone mines, by means of balancing elementary processes running inside of the plant and equipment. On the other hand, (González et al., 2007) proposed to incorporate the analysis of the dynamic performance of processes into the design and engineering stage of projects, by the use of base-software tools such as MATLAB/Simulink ${ }^{\circledR}$ package. These authors applied the simulation method obtained in MATLAB ${ }^{\circledR}$ in a natural gas installation in a power plant, in order to study the transients of a natural gas supply line to a steam-electric power plant. The results of the model were validated with actual data on the boiler trip obtained from the distributed control system. Finally, (Asbjörnsson, 2013) demonstrate that three different application areas of crushing/screening plants are available for dynamic, steady-state simulation using $M A T L A B^{\circledR}$ tools: plant performance, optimization and operator training, were each of these areas put different constraints on the modelling and simulation of these types of plants. 


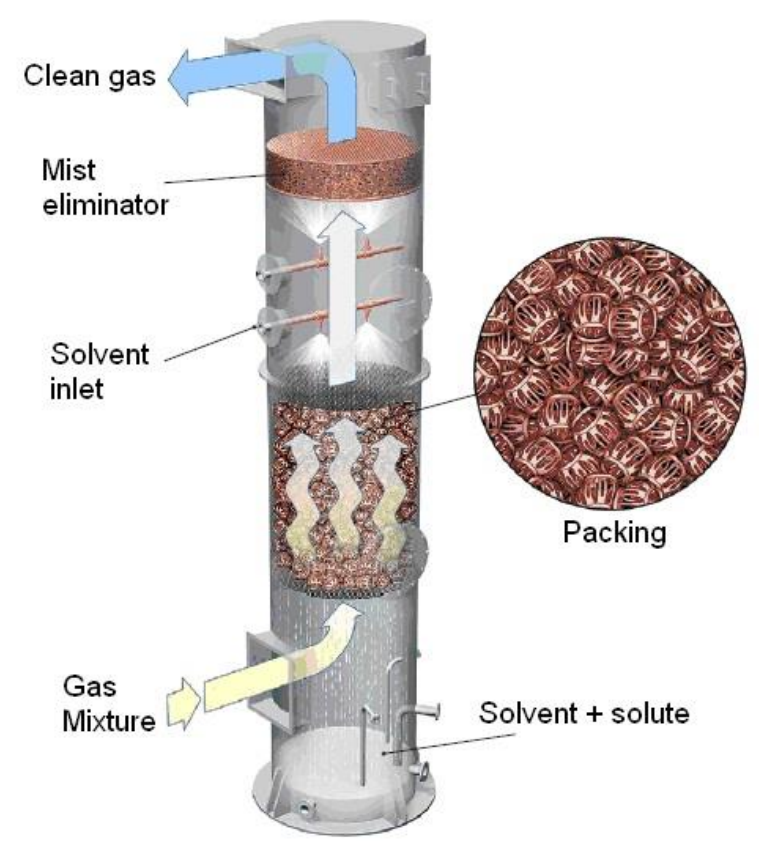

Figure 1. Typical layout of a packed-bed absorber Source: (Benitez, 2009)

At the present work, a packed bed absorber is designed to recover certain amounts of ethanol contained in a $\mathrm{CO}_{2}$-rich gaseous stream coming from fermentation operations. Four different packing types $\left(\right.$ Pall $^{\circledR}$, Hiflow ${ }^{\circledR}$, Top Pak ${ }^{\circledR}$ and VSP $^{\circledR}$ ) were evaluated in order to determine which packing configuration provides the lowest column dimensions (tower diameter and packing height) as well as the highest mass-transfer coefficient for this application, without exceeding the maximum allowable pressure drop and also without affecting the requested removal efficiency. The influence of both liquid solvent and gas mixture feed flowrates on 4 important process parameters (tower diameter, packing height, gas pressure drop and overall mass-transfer coefficient) was assessed for the four packing, while the effect of this two flowrates on two design parameters (overall number of gas-phase transfer units; $N_{t O G}$ and overall height of a gas-phase transfer unit, $\left.H_{t O G}\right)$ was also determined. The design methodology was solved using computing software $M A T L A B^{\circledR}$ version 7.8.0.347 (R2009a) (Math Works, 2009), and also Microsoft Excel ${ }^{\circledR}$ spreadsheet.

\section{MATERIALS AND METHODS}

\subsection{Problem description}

A gaseous mixture containing $\mathrm{CO}_{2}$ and ethanol, with a molar composition of $92 \% \mathrm{CO}_{2}$ and $8 \%$ of the alcohol, is evolved from a fermentation process. The ethanol must be recovered by means of a countercurrent absorption process using water as the solvent (Figure 3). The gas mixture will enter the tower at a rate of $4000 \mathrm{~m}^{3} / \mathrm{h}$, at $25^{\circ} \mathrm{C}(298 \mathrm{~K})$ and $1.1 \mathrm{~atm}$, while the solvent (water) will be supplied at a flowrate of $6500 \mathrm{~kg} / \mathrm{h}$ and also at $298 \mathrm{~K}$. The required recovery of ethanol will be $97.0 \%$, while the maximum pressure drop permitted for the gas stream should not exceed $250 \mathrm{~Pa} / \mathrm{m}$ of packed height. It's desired to design a suited packed-bed absorber working at $70 \%$ of flooding and operating under isothermal conditions.

For this application, four packing types will be evaluated (Figure 2):

1. 50-mm metal Hiflow ${ }^{\circledR}$ rings

2. 50-mm ceramic Pall $^{\circledR}$ rings

3. 50-mm metal Top Pak ${ }^{\circledR}$ rings, and

4. 25-mm metal $V S P^{\circledR}$ rings. 


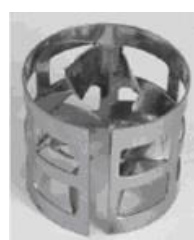

(a)

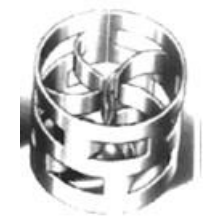

(b)

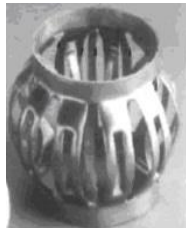

(c)

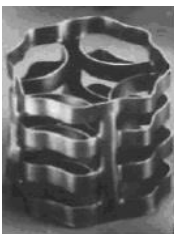

(d)

Figure 2. Configuration of the different packing types used:

(a) Metal Hiflow ${ }^{\circledR}$ rings

(b) Ceramic Pall ${ }^{\circledR}$ rings

(c) Metal Top Pak ${ }^{\circledR}$ rings

(d) Metal VSP ${ }^{\circledR}$ rings

Source: (Ludwig, 1997)

According to (Ludwig, 1997), the four packing types considered have the following performance and mass-transfer characteristics:

Table 1. Performance and mass-transfer characteristics of the different packing considered

\begin{tabular}{cccc}
\hline Packing & Mass Transfer & Pressure Drop & Capacity \\
\hline Hiflow $^{\circledR}$ & High & Low-Medium & Medium-High \\
Pall $^{\circledR}$ & Medium & Medium & Medium \\
Top Pak $^{\circledR}$ & High & Low & High \\
VSP $^{\circledR}$ & High & Medium & High \\
\hline
\end{tabular}

Table 2. Hydraulic and mass-transfer parameters of the four packing types selected

\begin{tabular}{|c|c|c|c|c|c|c|c|}
\hline \multirow[t]{2}{*}{ Packing type } & \multicolumn{5}{|c|}{ Hydraulic parameters } & \multicolumn{2}{|c|}{$\begin{array}{c}\text { Mass-transfer } \\
\text { parameters }\end{array}$} \\
\hline & $a$ & $\varepsilon$ & Ch & $C_{P}$ & $F p$ & $C_{L}$ & $C_{V}$ \\
\hline 50-mm Metal Hiflow ${ }^{\circledR}$ rings & 92.0 & 0.977 & 0.876 & 0.421 & 52 & 1.168 & 0.408 \\
\hline 50-mm Ceramic Pall ${ }^{\circledR}$ rings & 121.0 & 0.783 & 1.335 & 0.662 & 142 & 1.227 & 0.415 \\
\hline 50-mm Metal Top Pak ${ }^{\circledR}$ rings & 75.0 & 0.98 & 0.881 & 0.604 & 46 & 1.326 & 0.389 \\
\hline 25-mm Metal VSP ${ }^{\circledR}$ rings & 205.0 & 0.97 & 1.369 & 0.782 & 105 & 1.376 & 0.405 \\
\hline
\end{tabular}

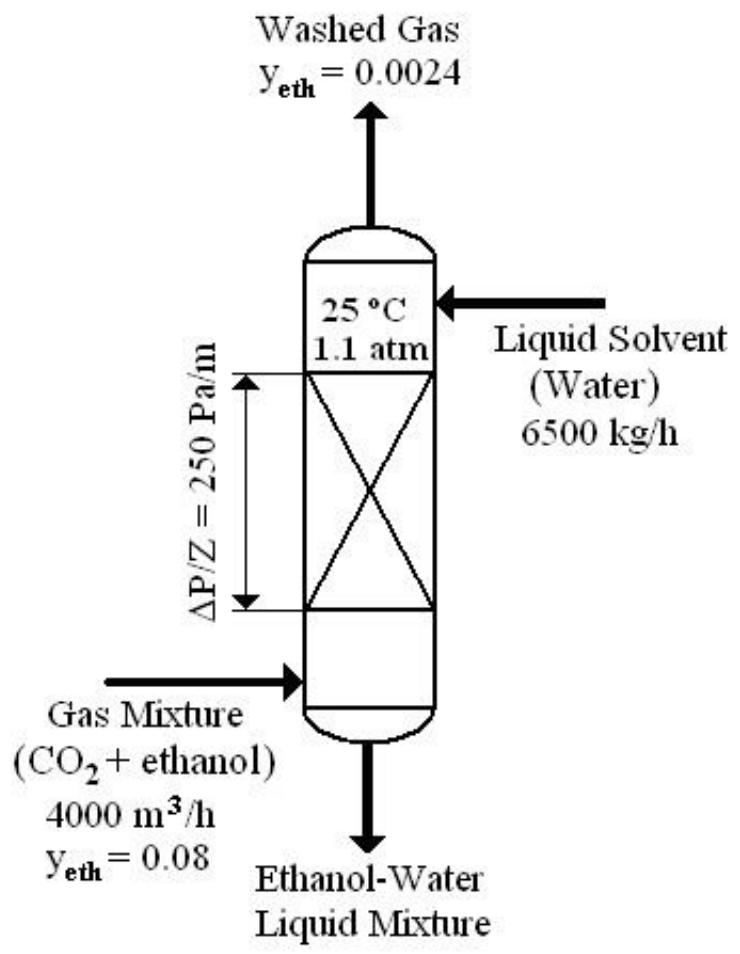

Figure. 3. Schematic drawing of the packed-bed absorber operating conditions 
Since the absorption system operates at low pressure and temperature $(1.1$ atm and $298 \mathrm{~K}$, respectively); the solute gas is very diluted in the liquid phase (that is, the liquid phase can be catalogued as a dilute liquid solution), the system operates under isothermal conditions and there is no reaction between the dissolved solute (ethanol) and the solvent (water), it's assumed that the system obeys the Henry's law (Leye and Froment, 1986) (Matos and Hing, 1990) (Perry and Chilton, 2008) (Richardson and Harker, 2002) (Treybal, 1980). According to (Perry and Chilton, 2008) (Rogers, 2007), the value of the Henry's constant for an ethanol-water system operating at $25^{\circ} \mathrm{C}$ is $\mathrm{H}=0.272$ atm. Thus, the distribution coefficient ( $\phi$ ) for the gas-liquid system (ethanol-water system) at $25{ }^{\circ} \mathrm{C}$ and $1.1 \mathrm{~atm}$ is $\phi=\mathrm{H} / \mathrm{P}=0.272 / 1.1=0.229$.

\subsection{Packing hydraulic and mass-transfer parameters}

The most important hydraulic/mass transfer characteristics of the four packing types selected are described in the Table 2 (Billet, 1989) (Perry and Chilton, 2008).

\subsection{Inlet data}

The inlet data necessary to carry out the design calculations are showed in Table 3 :

Table 3. Inlet data of the absorption process

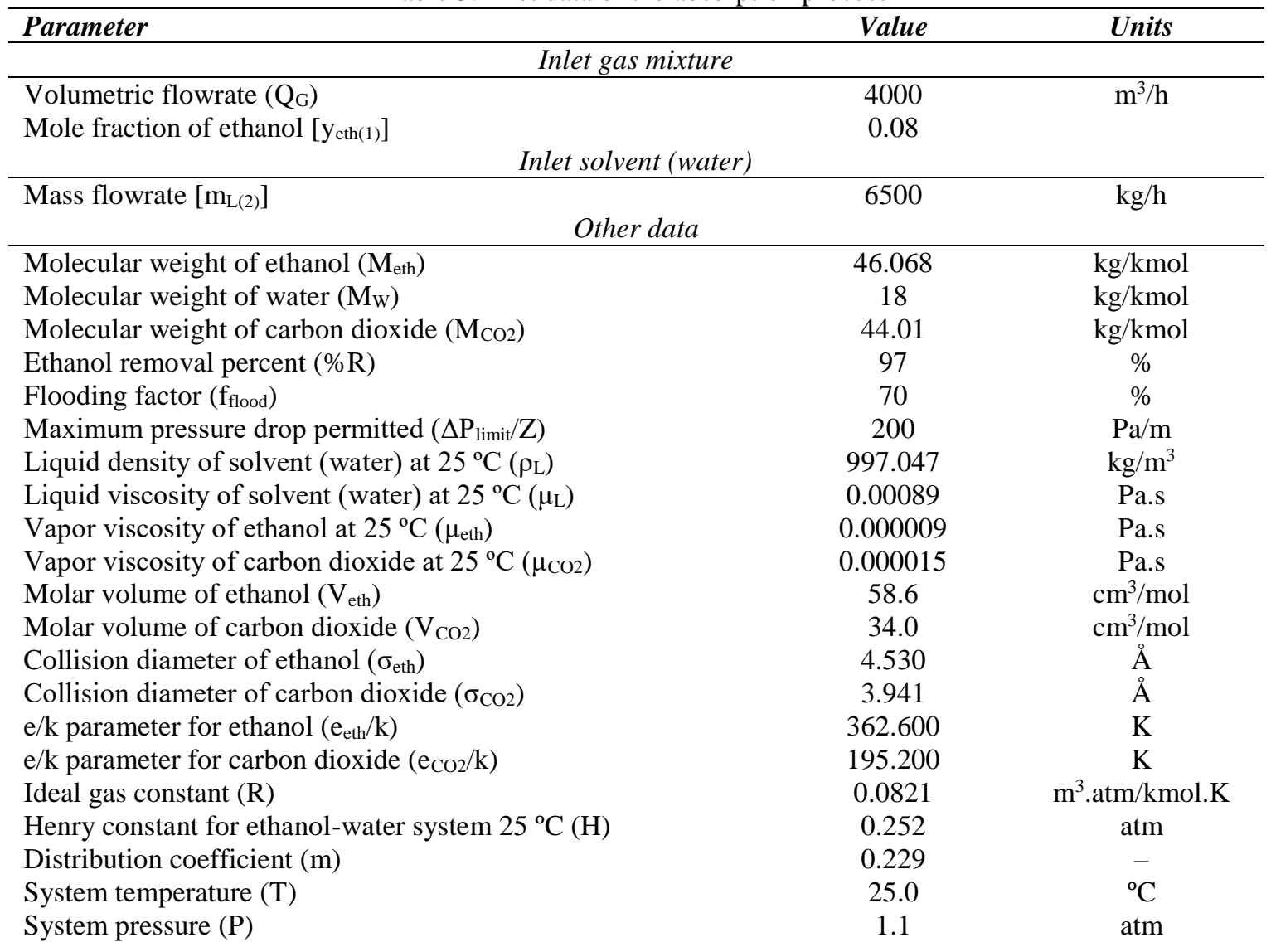

\subsection{Design methodology}

The equations and correlations used to design the packed-bed absorber were taken from different sources (Billet, 1989) (Perry and Chilton, 2008) (Richardson and Harker, 2002), considering several aspects such as process operating conditions, mass transfer characteristics, and packing type. 


\subsubsection{Tower diameter}

The molecular weight of the gas mixture $\left(M_{G}\right)$ was determined applying the equation (1):

$$
M_{G}=\left(y_{e t h(1)} \cdot M_{e t h}\right)+\left(y_{C O 2(1)} \cdot M_{C O 2}\right)
$$

where $\mathrm{y}_{\mathrm{CO} 2(1)}=1-\mathrm{y}_{\mathrm{eth}(1)}$.

The gas mixture density $\left(\rho_{G}\right)$ at $25{ }^{\circ} \mathrm{C}$ was determined using the Kay's method (Perry and Chilton, 2008), while the viscosity of the gas mixture $\left(\mu_{G}\right)$ was calculated using the following correlation (Pavlov, 1981):

$$
\mu_{G}=\left[\frac{M_{G}}{\left(\frac{y_{e t h(1)} \cdot M_{e t h}}{\mu_{e t h}}\right)+\left(\frac{y_{\operatorname{CO} 2(1)} \cdot M_{C O 2}}{\mu_{C O 2}}\right)}\right] \cdot 0.001
$$

where $\mu_{\mathrm{eth}}$ and $\mu_{\mathrm{CO} 2}$ values are given in $\mathrm{cP}$.

The amount of ethanol absorbed is;

$$
m_{e t h(a b s)}=\left(\frac{Q_{G} \cdot \rho_{G}}{M_{G}}\right) \cdot y_{e t h(1)} \cdot \% R \cdot M_{e t h}
$$

The amount of solvent liquid exiting the column is:

$$
m_{L(1)}=m_{L(2)}+m_{\text {eth }(a b s)}
$$

The flow parameter $(X)$, the pressure drop parameter under flooding conditions $\left(Y_{\text {flood }}\right)$ and the $C_{S}$ coefficient at flooding conditions $\left(C_{\text {Sflood }}\right)$ were determined according to the equations (5) (6) and (7), respectively.

$$
\begin{gathered}
X=\frac{m_{L(1)}}{Q_{G} \cdot \rho_{G}} \cdot\left(\frac{\rho_{G}}{\rho_{L}}\right)^{0.5} \\
\ln Y_{\text {flood }}=-\left[3.5021+1.028 \cdot \ln X+0.11093 \cdot(\ln X)^{2}\right\rfloor \\
C_{\text {Sflood }}=\left[\frac{Y_{\text {flood }}}{F_{P} \cdot \mu_{L}^{0.1}}\right]^{0.5}
\end{gathered}
$$

The gas velocity at flooding conditions $\left(v_{G f l o o d}\right)$, the gas velocity $\left(v_{G}\right)$, and finally the tower diameter $(D)$, were calculated by using the following correlations:

$$
\begin{gathered}
v_{\text {Gflood }}=\frac{C_{\text {Sflood }}}{\left[\frac{\rho_{G}}{\rho_{L}-\rho_{G}}\right]^{0.5}} \\
v_{G}=v_{\text {Gflood }} \cdot f_{\text {flood }} \\
D=\left[\frac{4 \cdot\left(\frac{Q_{G}}{3600}\right)}{v_{G} \cdot \pi}\right]^{0.5}
\end{gathered}
$$

2.4.2. Pressure drop 
Most packed-bed absorbers are designed to safely avoid flooding conditions and also to operate in the preloading region, with a gas-pressure drop limit of $200-400 \mathrm{~Pa} / \mathrm{m}$ of packed depth [4]. In this approach, both the gas dry pressure drop $\left(\Delta \mathrm{P}_{0} / \mathrm{Z}\right)$ and overall pressure drop $(\Delta P / Z)$ were determined for the absorption process using well-accepted equations. The liquid holdup influence was also taken into account, that is, when the packed bed is irrigated, the liquid holdup causes an increment of the pressure drop (Benitez, 2009) (Perry and Chilton, 2008). Prior to the determination of both pressure drops, it was necessary to determine several parameters first. Among those parameters are included the effective particle diameter $\left(d_{P}\right)$ [equation (11)]; the wall factor $\left(K_{W}\right)$ [eq. (12)]; the gas-phase Reynolds number $\left(\operatorname{Re}_{G}\right)$ [eq. (13)]; the dry-packing resistance coefficient $\left(\psi_{0}\right)$ [eq. (14)]; liquid mass velocity $\left(\mathrm{G}_{\mathrm{L}}\right)$ [eq. (15)]; the liquid velocity $\left(v_{L}\right)$ [eq.(16)]; the liquid-phase Reynolds number $\left(\operatorname{Re}_{L}\right)$ [eq.(17)]; liquid-phase Froude number $\left(F r_{L}\right)$ [eq.(18)]; the ratio $a_{h} / a$ [eq. (19)]; the effective specific surface area of packing $\left(a_{\mathrm{h}}\right)$ [eq. (20)]; and, finally, the liquid holdup $\left(h_{L}\right)$ [eq. (21)].

$$
\begin{gathered}
d_{P}=6 \cdot\left(\frac{1-\varepsilon}{a}\right) \\
K_{W}=\frac{1}{1+\frac{2}{3} \cdot\left(\frac{1}{1-\varepsilon}\right) \cdot \frac{d_{P}}{D}} \\
\operatorname{Re}_{G}=\frac{v_{G} \cdot d_{P} \cdot \rho_{G} \cdot K_{W}}{(1-\varepsilon) \cdot \mu_{G}} \\
\psi_{0}=C_{P} \cdot\left(\frac{64}{\operatorname{Re}_{G}}+\frac{1.8}{\operatorname{Re}_{G}^{0.08}}\right) \\
G_{L}=\frac{\left(\frac{m_{L}(1)}{3600}\right)}{\pi \cdot D^{2}} \\
C_{h} \cdot \operatorname{Re}_{L}^{0.5} \cdot F r_{L}^{0.1} \text { for } \operatorname{Re}_{\mathrm{L}}<5 \\
C_{h} \cdot \operatorname{Re}_{L}^{0.25} \cdot F r_{L}^{0.1} \text { for } \operatorname{Re}_{\mathrm{L}} \geq 5 \\
\operatorname{Re}_{L}=\frac{a_{h}}{a} \cdot \frac{G_{L}}{\rho_{L}} \\
\frac{v_{L} \cdot \rho_{L}}{g}
\end{gathered}
$$




$$
h_{L}=\left[12 \cdot \frac{F r_{L}}{\operatorname{Re}_{L}}\right]^{1 / 3} \cdot\left[\frac{a_{h}}{a}\right]^{2 / 3}
$$

The gas dry pressure drop per meter of packing height $\left(\Delta \mathrm{P}_{0} / \mathrm{Z}\right)$ was determined according to the following correlation:

$$
\frac{\Delta P_{0}}{Z}=\psi_{0} \cdot \frac{a}{\varepsilon^{3}} \cdot \frac{\rho_{G} \cdot v_{G}^{2}}{2} \cdot \frac{1}{K_{W}}
$$

Then, the gas overall pressure drop per meter of packing height $(\Delta \mathrm{P} / \mathrm{Z})$ can be finally calculated:

$$
\frac{\Delta P}{Z}=\frac{\Delta P_{0}}{Z} \cdot\left[\left(\frac{\varepsilon}{\varepsilon-h_{L}}\right)^{1.5} \exp \left(\frac{\operatorname{Re}_{L}}{200}\right)\right]
$$

\subsubsection{Diffusion coefficients}

Gas-phase diffusion coefficient: The theory describing diffusion processes in binary gas mixtures at low to moderate pressures has been studied extensively in recent years, and is well developed nowadays. Since the absorption process is a binary gas system taking place at low-pressure, the gasphase diffusion coefficient can be estimated using the Wilke and Lee correlation (Benitez, 2009):

where:

$$
D_{G}=\frac{\left[3.03-\left(\frac{0.98}{M_{A B}^{1 / 2}}\right)\right] \cdot\left(10^{-3}\right) \cdot T^{3 / 2}}{P \cdot M_{A B}^{1 / 2} \cdot \sigma_{A B}^{2} \cdot \Omega_{D}} \cdot 0.0001
$$

$$
\begin{gathered}
M_{A B}=2 \cdot\left[\frac{1}{M_{e t h}}+\frac{1}{M_{C O 2}}\right]^{-1} \\
\sigma_{\mathrm{AB}}-\text { Collision diameter } \\
\sigma_{\mathrm{AB}}=\frac{\sigma_{e t h}+\sigma_{C O 2}}{2} \\
\Omega_{D}=\frac{1.06036}{\left(T^{*}\right)^{0.15610}}+\frac{\Omega_{\mathrm{D}}-\text { Diffusion collision integral }}{\exp (0.476300}+\frac{1.03587}{\exp \left(1.52996 \cdot T^{*}\right)}+\frac{1.76474}{\exp \left(3.89411 \cdot T^{*}\right)} \\
T^{*}=\frac{T}{\sqrt{\frac{e_{e t h}}{k} \cdot \frac{e_{C O 2}}{k}}}
\end{gathered}
$$

Liquid-phase diffusion coefficient: Compared with the kinetic theory behind the gases behavior, which is well developed and available today, the theoretical basis of the internal structure of liquids and their transport characteristics are still insufficient to permit a rigorous treatment (Benitez, 2009) (Billet, 1989). Usually, liquid diffusion coefficients are several orders of magnitude smaller than gas diffusivities, and depend mostly on concentration profiles due to changes in viscosity, as well as some changes in the degree of ideality of the solution. To determine the liquid-phase diffusion coefficient in binary systems for solutes transport to aqueous solutions, the Hayduk and Minhas correlation was used (Benitez, 2009): 
where:

$$
D_{L}=\frac{1.25 \times 10^{-8}\left(V_{\text {eth }}^{-0.19}-0.292\right) \cdot T^{1.52} \cdot \mu_{W}^{n}}{10000}
$$

$\mathrm{V}_{\text {eth }}$ - Molar volume of ethanol [see Table (2)] [ $\left.\mathrm{cm}^{3} / \mathrm{mol}\right]$

$\mu_{\mathrm{W}}-$ Viscosity of water at temperature $\mathrm{T}[\mathrm{cP}]$

$$
n=\frac{9.58}{V_{\text {eth }}}-1.12
$$

\subsubsection{Mass transfer coefficients}

To determine the mass transfer coefficients for both phases, two correlations were used which were obtained from an extensive study made by Billet and Schultes (Billet, 1989), that involved measurement and correlation of mass-transfer coefficients for 31 different binary and ternary systems, equipped with 67 different types and sizes of packings, in columns of diameter ranging from $6 \mathrm{~cm}$ to $1.4 \mathrm{~m}$.

Gas-phase convective mass-transfer coefficient $\left(k_{G}\right)$ :

$$
k_{G}=0.1304 \cdot C_{V} \cdot\left[\frac{D_{G} \cdot P}{R \cdot T}\right] \cdot\left(\frac{a}{\left[\varepsilon\left(\varepsilon-h_{L}\right)\right]^{0.5}}\right) \cdot\left[\frac{\mathrm{Re}_{G}}{K_{W}}\right]^{3 / 4} \cdot S c_{G}^{2 / 3}
$$

where:

$\mathrm{C}_{\mathrm{V}}$ - Mass transfer factor [see Table (1)]

$\mathrm{R}$ - Ideal gas constant

$=0.0821 \mathrm{~m}^{3} \cdot \mathrm{atm} / \mathrm{kmol} \cdot \mathrm{K}$

$\varepsilon-$ Packing porosity or void fraction [see

Table (1)]

$\mathrm{Sc}_{\mathrm{G}}-$ Schmidt number for gas phase $=\frac{\mu_{G}}{\rho_{G} \cdot D_{G}}$

Liquid-phase convective mass-transfer coefficient $\left(k_{L}\right)$ :

$$
k_{L}=0.757 \cdot C_{L} \cdot\left[\frac{D_{L} \cdot a \cdot v_{L}}{\varepsilon \cdot h_{L}}\right]^{0.5}
$$

where:

$\mathrm{C}_{\mathrm{L}}$ - Mass transfer factor [see Table (1)]

$a$ - Mass transfer surface area per unit volume [see Table (1)] $\left[\mathrm{m}^{2} / \mathrm{m}^{3}\right]$

\subsubsection{Packing Height}

In those systems handling dilute solutions and when Henry's law applies, is very usual and convenient to work with overall mass-transfer coefficients in order to calculate the packing height $(Z)$, which can be determined by the following expression:

$$
Z=H_{t O G} \cdot N_{t O G}
$$

where:

$\mathrm{H}_{\mathrm{tOG}}-$ Overall height of a gas-phase transfer unit (HTU) [m] 
$\mathrm{N}_{\mathrm{tOG}}-$ Overall number of gas-phase transfer units (NTU)

Prior to determine the values of HTU and NTU, it will be necessary to calculate several parameters first, which are the inlet gas molar velocity $\left[G_{M y(1)}\right]$ [equation (38)]; the outlet gas molar velocity $\left[G_{M y(2)}\right]$ [eq. (39)]; the average molar gas velocity $\left(G_{M_{y}}\right)$ [eq. (40)]; the inlet liquid molar velocity $\left[G_{M x(2)}\right]$ [eq. (41)]; the outlet liquid molar velocity $\left[G_{M x(1)}\right]$ [eq. (42)]; the absorption factor at the bottom $\left[A_{(1)}\right]$ and top $\left[A_{(2)}\right]$ of the column [eqs. (43) and (44)]; the geometric average of the absorption factor (A) [eq. (45)]; the ethanol molar composition of outlet gas [yeth(2)] [eq. (46)]; the volumetric gasphase $\left(K_{v G}\right)$ and liquid-phase $\left(K_{v L}\right)$ mass-transfer coefficients [eqs. (47) and (48), respectively]; the overall volumetric mass-transfer coefficient $\left(K_{m}\right)$ [eq. (49)]; the overall height of a gas-phase transfer unit $\left(H_{t O G}\right)$ [eq. (50)]; the overall number of gas-phase transfer units $\left(N_{t O G}\right)$ [eq. $(51)$; and finally the packing height (Z) [eq. (37)].

$$
G_{M y(1)}=\frac{4 \cdot N_{G}}{3600 \cdot \pi \cdot D^{2}}
$$

where:

$\mathrm{N}_{\mathrm{G}}-$ Gas molar flowrate

$$
N_{G}=\left(\frac{Q_{G} \cdot \rho_{G}}{M_{G}}\right)
$$

where:

$$
G_{M y(2)}=\frac{4 \cdot\left(N_{G}-N_{e t h(a b s)}\right)}{3600 \cdot \pi \cdot D^{2}}
$$

$\mathrm{N}_{\text {eth(abs) }}$ - Molar flow of ethanol absorbed

$$
N_{e t h(a b s)}=\left(\frac{Q_{G} \cdot \rho_{G}}{M_{G}}\right) \cdot y_{e t h(1)} \cdot \% R
$$

$$
\begin{gathered}
G_{M y}=\frac{G_{M y(1)}+G_{M y(2)}}{2} \\
G_{M x(2)}=\frac{4 \cdot N_{L(2)}}{3600 \cdot \pi \cdot D^{2}}
\end{gathered}
$$

where:

$\mathrm{N}_{\mathrm{L}(2)}$ - Inlet liquid molar flowrate [kmol/h]

$$
N_{L(2)}=\left(\frac{m_{L(2)}}{M_{W}}\right)
$$

$$
\begin{gathered}
G_{M x(1)}=\frac{4 \cdot\left(N_{L(2)}+N_{e t h(a b s)}\right)}{3600 \cdot \pi \cdot D^{2}} \\
A_{(1)}=\frac{G_{M x(1)}}{G_{M y(1)} \cdot \phi} \\
A_{(2)}=\frac{G_{M x(2)}}{G_{M y(2)} \cdot \phi}
\end{gathered}
$$

where: 
$\phi-$ Distribution coefficient $=0.229$

$$
\begin{gathered}
A=\frac{A_{(1)}+A_{(2)}}{2} \\
y_{e t h(2)}=(100-\% R) \cdot y_{\text {eth }(1)} \\
K_{v G}=k_{G} \cdot a_{h} \\
K_{v L}=k_{L} \cdot a_{h} \cdot c
\end{gathered}
$$

where:

$c=\frac{\rho_{L}}{M_{W}}$

$$
\begin{gathered}
K_{m}=\frac{1}{\frac{1}{K_{v G}}+\frac{\phi}{K_{v L}}} \\
H_{t O G}=\frac{G_{M y}}{K_{m}} \\
N_{t O G}=\frac{\ln \left\{\left[\frac{y_{e t h(1)}-\left(\phi \cdot x_{\text {eth }(2)}\right)}{y_{\text {eth }(2)}-\left(\phi \cdot x_{\text {eth }(2)}\right)} \cdot\left(1-\frac{1}{A}\right)\right]+\frac{1}{A}\right\}}{1-\frac{1}{A}}
\end{gathered}
$$

2.4.6. Operating and equilibrium lines

The operating line will be elaborated using the following data:

- Mole fraction of ethanol in inlet gas mixture $\left[\mathrm{y}_{\mathrm{eth}(1)}\right]=0.08$

- Mole fraction of ethanol in outlet gas mixture $\left[\mathrm{y}_{\mathrm{eth}(2)}\right]=0.0024$

- Mole fraction of ethanol in inlet liquid $\left[\mathrm{x}_{\mathrm{eth}(2)}\right]=0$.

- Mole fraction of ethanol in outlet liquid

$$
\left[x_{e t h(1)}\right]=\frac{N_{e t h(a b s)}}{N_{L(1)}}=\frac{N_{e t h(a b s)}}{N_{L(2)}+N_{e t h(a b s)}}=0.038
$$

While to elaborate the equilibrium line, the following expression will be used:

$$
y^{*}=\phi \cdot x
$$

\section{RESULTS AND DISCUSSION}

The main physical parameters calculated for the gas mixture (that is, molecular weight, density and viscosity) are showed in Table 4, while the calculated tower diameter (D) and overall gas pressure drop $(\triangle \mathrm{P} / \mathrm{Z})$ values for each packing type, among other important design variables, are showed in Table 5 . 
Table 6 shows the calculated values of the diffusion and convective mass-transfer coefficients for both fluids (gas and liquid), whereas the values obtained of packing height $(Z)$ and other significant flow and mass-transfer parameters are listed in Table 7, all of them for the four packing types selected.

Finally, Table 8 presents a summary of the most important geometrical and mass-transfer parameters calculated for the four packing types.

Figure 4 shows a graphical comparison between $Z$ and $D$ for each packing type; while the values obtained of gas pressure drop and overall mass-transfer coefficient for each packing are given in Figure 5 and Figure 6, respectively.

The resulting values of tower diameter; gas pressure drop; overall mass-transfer coefficient and packing height for each packing as a function of gas mixture feed flowrate $\left(Q_{G}\right)$ and liquid solvent feed flowrate $\left(m_{L}\right)$ are reported in Figure 7 and Figure 8, respectively. The behavior of the variables $N_{t O G}$ and $H_{t O G}$ with respect to $Q_{G}$ and $m_{L}$ are showed in Figure 9 and Figure 10, respectively. Finally, both the operating and equilibrium lines are illustrated in Figure 11.

Table 4. Calculated physical parameters

\begin{tabular}{lccc}
\hline Parameter & Units & Equation No. & Value \\
\hline Gas mixture molecular weight $\left[\mathrm{M}_{\mathrm{G}}\right]$ & $\mathrm{kg} / \mathrm{kmol}$ & $(1)$ & 44.17 \\
Gas mixture density $\left[\rho_{\mathrm{G}}\right]$ & $\mathrm{kg} / \mathrm{m}^{3}$ & & 2.006 \\
Gas mixture viscosity $\left[\mu_{\mathrm{G}}\right]$ & $\mathrm{Pa} . \mathrm{s}$ & $(2)$ & 0.0000142 \\
\hline
\end{tabular}

Table 5. Tower diameter and pressure drop results for each packing type

\begin{tabular}{|c|c|c|c|c|c|c|}
\hline Parameter / Packing & Units & $E q$. & Hiflow $^{\circledR}$ & Pall $^{\circledR}$ & Top Pak ${ }^{\circledR}$ & $\boldsymbol{V S P} \boldsymbol{P}^{\circledR}$ \\
\hline $\mathrm{m}_{\mathrm{eth}(\mathrm{abs})}$ & $\mathrm{kg} / \mathrm{h}$ & (3) & 649.35 & 649.35 & 649.35 & 649.35 \\
\hline $\mathrm{m}_{\mathrm{L}(1)}$ & $\mathrm{kg} / \mathrm{h}$ & (4) & 7149.35 & 7149.35 & 7149.35 & 7149.35 \\
\hline $\mathrm{X}$ & - & (5) & 0.0400 & 0.0400 & 0.0400 & 0.0400 \\
\hline$Y_{\text {flood }}$ & & (6) & 0.261 & 0.261 & 0.261 & 0.261 \\
\hline $\mathrm{C}_{\text {Sflood }}$ & & (7) & 0.101 & 0.061 & 0.107 & 0.071 \\
\hline$v_{\mathrm{GF}}$ & $\mathrm{m} / \mathrm{s}$ & (8) & 2.243 & 1.357 & 2.385 & 1.578 \\
\hline$v_{\mathrm{G}}$ & $\mathrm{m} / \mathrm{s}$ & (9) & 1.570 & 0.950 & 1.669 & 1.105 \\
\hline$D$ & $\mathrm{~m}$ & (10) & 0.949 & 1.221 & 0.921 & 1.132 \\
\hline $\mathrm{d}_{\mathrm{P}}$ & $\mathrm{m}$ & (11) & 0.0015 & 0.0108 & 0.0016 & 0.0006 \\
\hline $\mathrm{K}_{\mathrm{W}}$ & & (12) & 0.956 & 0.974 & 0.945 & 0.983 \\
\hline $\operatorname{Re}_{\mathrm{G}}$ & & (13) & 13822.75 & 6475.80 & 17821.18 & 4466.63 \\
\hline$\psi_{0}$ & & (14) & 0.355 & 0.597 & 0.499 & 0.730 \\
\hline $\mathrm{G}_{\mathrm{L}}$ & $\mathrm{kg} / \mathrm{m}^{2} \cdot \mathrm{s}$ & (15) & 2.806 & 1.698 & 2.984 & 1.975 \\
\hline$v_{\mathrm{L}}$ & $\mathrm{m} / \mathrm{s}$ & (16) & 0.0028 & 0.0017 & 0.0030 & 0.0020 \\
\hline $\operatorname{Re}_{\mathrm{L}}$ & & (17) & 34.27 & 15.77 & 44.70 & 10.77 \\
\hline $\mathrm{Fr}_{\mathrm{L}}$ & & (18) & 0.000074 & 0.000036 & 0.000068 & 0.00082 \\
\hline Ratio $a_{h} / a$ & & (19) & 0.696 & 0.812 & 0.742 & 0.823 \\
\hline $\mathbf{a}_{\mathbf{h}}$ & $\mathrm{m}^{-1}$ & (20) & 64.05 & 98.29 & 55.66 & 169.57 \\
\hline$h_{L}$ & & (21) & 0.0233 & 0.0262 & 0.0216 & 0.0396 \\
\hline$\Delta \mathrm{P}_{0} / \mathrm{Z}$ & $\mathrm{Pa} / \mathrm{m}$ & (22) & 91 & 140 & 118 & 199 \\
\hline$\Delta \mathbf{P} / \mathbf{Z}$ & $\mathrm{Pa} / \mathrm{m}$ & (23) & 112 & 159 & 152 & 223 \\
\hline
\end{tabular}

Table 6. Diffusion and mass-transfer coefficients for each packing type

\begin{tabular}{lcccccc}
\hline \multicolumn{1}{c}{$\begin{array}{c}\text { Parameter / } \\
\text { Packing }\end{array}$} & Units & Eq. & Hiflow $^{\circledR}$ & Pall $^{\circledR}$ & Top Pak $^{\circledR}$ & VSP $^{\circledR}$ \\
\hline $\mathrm{M}_{\mathrm{AB}}$ & & $(25)$ & 45.02 & 45.02 & 45.02 & 45.02 \\
$\sigma_{\mathrm{AB}}$ & $\AA$ & $(26)$ & 4.236 & 4.236 & 4.236 & 4.236 \\
$\Omega_{\mathrm{D}}$ & & $(27)$ & 1.364 & 1.364 & 1.364 & 1.364 \\
$\mathrm{~T}^{*}$ & & $(28)$ & 1.120 & 1.120 & 1.120 & 1.120 \\
$\mathrm{D}_{\mathrm{G}}$ & $\mathrm{cm}^{2} / \mathrm{s}$ & $(24)$ & 0.0821 & 0.0821 & 0.0821 & 0.0821 \\
$\mathrm{D}_{\mathrm{L}}$ & $\mathrm{cm}^{2} / \mathrm{s}$ & $(29)$ & 0.0000136 & 0.0000136 & 0.0000136 & 0.0000136 \\
$\mathrm{k}_{\mathrm{G}}$ & ${\mathrm{kmol} / \mathrm{m}^{2} . \mathrm{s}}$ & $(31)$ & 0.00221 & 0.002061 & 0.00209 & 0.002056 \\
$\mathrm{Sc}_{\mathrm{G}}$ & & $(32)$ & 0.862 & 0.862 & 0.862 & 0.862 \\
$\mathrm{k}_{\mathrm{L}}$ & $\mathrm{m} / \mathrm{s}$ & $(33)$ & 0.000110 & 0.000109 & 0.000121 & 0.000125 \\
\hline
\end{tabular}

Table 7. Packing height determination for each packing type 
A. Pérez Sánchez et al

\begin{tabular}{|c|c|c|c|c|c|c|}
\hline $\begin{array}{c}\text { Parameter / } \\
\text { Packing }\end{array}$ & Units & Eq. No. & Hiflow $^{\circledR}$ & Pall $^{\circledR}$ & Top Pak ${ }^{\circledR}$ & $\boldsymbol{V S P} \boldsymbol{P}^{\circledR}$ \\
\hline $\mathrm{G}_{\mathrm{My}(1)}$ & $\mathrm{kmol} / \mathrm{m}^{2} . \mathrm{s}$ & (35) & 0.071 & 0.043 & 0.076 & 0.050 \\
\hline $\mathrm{G}_{\mathrm{My}(2)}$ & $\mathrm{kmol} / \mathrm{m}^{2} . \mathrm{s}$ & (36) & 0.066 & 0.040 & 0.070 & 0.046 \\
\hline $\mathrm{G}_{\mathrm{My}}$ & $\mathrm{kmol} / \mathrm{m}^{2} . \mathrm{s}$ & (37) & 0.069 & 0.041 & 0.073 & 0.048 \\
\hline $\mathrm{G}_{\mathrm{Mx}(2)}$ & $\mathrm{kmol} / \mathrm{m}^{2} . \mathrm{s}$ & (38) & 0.142 & 0.086 & 0.151 & 0.100 \\
\hline $\mathrm{G}_{\mathrm{Mx}(1)}$ & $\mathrm{kmol} / \mathrm{m}^{2} . \mathrm{s}$ & (39) & 0.147 & 0.089 & 0.157 & 0.104 \\
\hline $\mathrm{A}_{1}$ & & (40) & 9.017 & 9.017 & 9.017 & 9.017 \\
\hline $\mathrm{A}_{2}$ & & (41) & 9.408 & 9.408 & 9.408 & 9.408 \\
\hline A & & (42) & 9.212 & 9.212 & 9.212 & 9.212 \\
\hline Yeth(2) & & (43) & 0.0024 & 0.0024 & 0.0024 & 0.0024 \\
\hline$K_{v G}$ & $\mathrm{kmol} / \mathrm{m}^{3} \cdot \mathrm{s}$ & (44) & 0.142 & 0.203 & 0.116 & 0.349 \\
\hline$K_{v L}$ & $\mathrm{kmol} / \mathrm{m}^{3} \cdot \mathrm{s}$ & (45) & 0.391 & 0.592 & 0.372 & 1.172 \\
\hline$K_{m}$ & $\mathrm{kmol} / \mathrm{m}^{3} \cdot \mathrm{s}$ & (46) & 0.131 & 0.188 & 0.109 & 0.326 \\
\hline $\boldsymbol{H}_{t O G}$ & $\mathrm{~m}$ & (47) & 0.524 & 0.221 & 0.671 & 0.148 \\
\hline $\mathrm{N}_{\mathrm{tOG}}$ & & (48) & 3.809 & 3.809 & 3.809 & 3.809 \\
\hline$Z$ & $\mathrm{~m}$ & (34) & 2.0 & 0.8 & 2.6 & 0.6 \\
\hline
\end{tabular}

Table 8. Summary of the most important packed column design parameters for the four packing considered

\begin{tabular}{lcccc}
\hline Parameter & Hiflow $^{\circledR}$ & Pall $^{\circledR}$ & Top Pak $^{\circledR}$ & VSP $^{\circledR}$ \\
\hline $\mathrm{D}[\mathrm{m}]$ & 0.949 & 1.221 & 0.921 & 1.132 \\
$\mathrm{Z}[\mathrm{m}]$ & 2.00 & 0.80 & 2.60 & 0.60 \\
$\Delta \mathrm{P} / \mathrm{Z}[\mathrm{Pa} / \mathrm{m}]$ & 112 & 159 & 152 & 223 \\
$\mathrm{~K}_{\mathrm{VG}}\left[\mathrm{kmol} / \mathrm{m}^{3} . \mathrm{s}\right]$ & 0.142 & 0.203 & 0.116 & 0.349 \\
$\mathrm{~K}_{\mathrm{vL}}\left[\mathrm{kmol} / \mathrm{m}^{3} . \mathrm{s}\right]$ & 0.391 & 0.592 & 0.372 & 1.172 \\
$\mathrm{~K}_{\mathrm{m}}\left[\mathrm{kmol} / \mathrm{m}^{3} . \mathrm{s}\right]$ & 0.131 & 0.188 & 0.109 & 0.326 \\
$\mathrm{H}_{\mathrm{tOG}}[\mathrm{m}]$ & 0.524 & 0.221 & 0.671 & 0.148 \\
$a_{\mathrm{h}}\left[\mathrm{m}^{-1}\right]$ & 64.05 & 98.29 & 55.66 & 169.57 \\
\hline
\end{tabular}

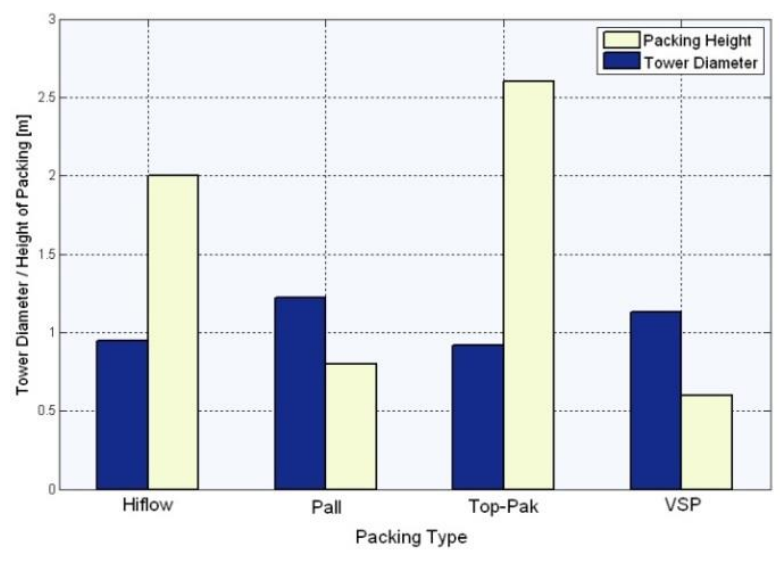

Figure 4. Comparison between Tower Diameter and Packing Height as a function of packing

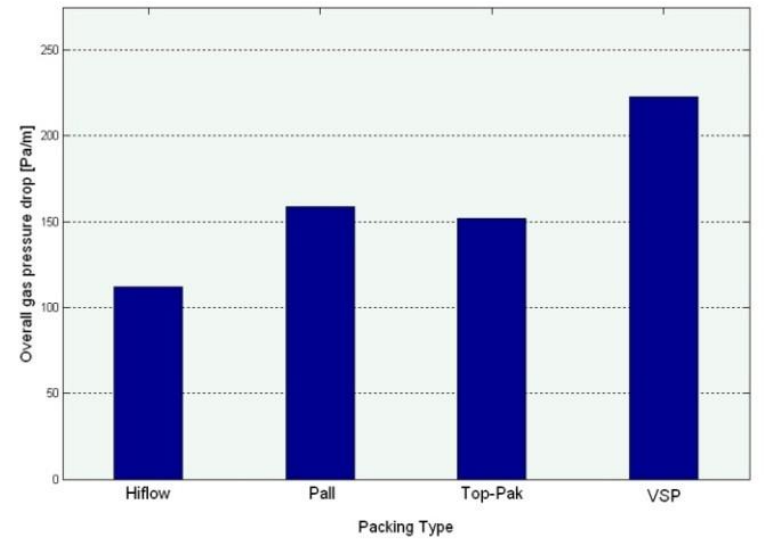

Figure 5. Overall gas pressure drop values determined for each packing 


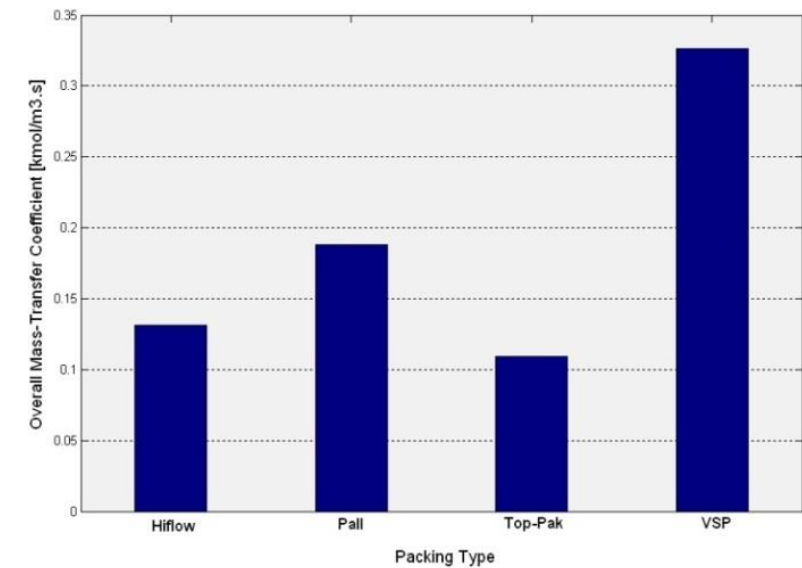

Figure 6. Overall Mass-Transfer Coefficients calculated for each packing
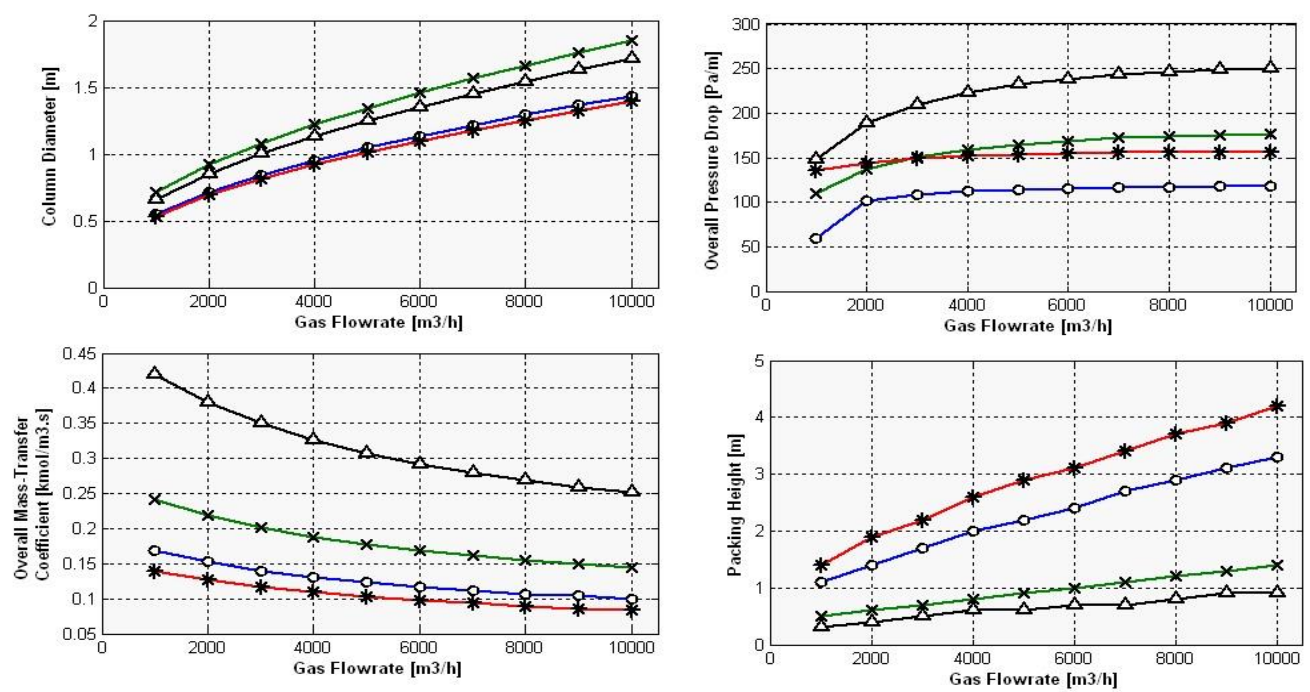

$\multimap$ - Hiflow $\rightarrow$ - Pall $\rightarrow$ * Top-Pak $\neg-$ VSP

Figure 8. Calculated Tower Diameter; Gas Pressure-Drop; Overall Mass-Transfer Coefficients and Packing Height values for the different packing types as a function of Gas Mixture Feed Flowrate. 

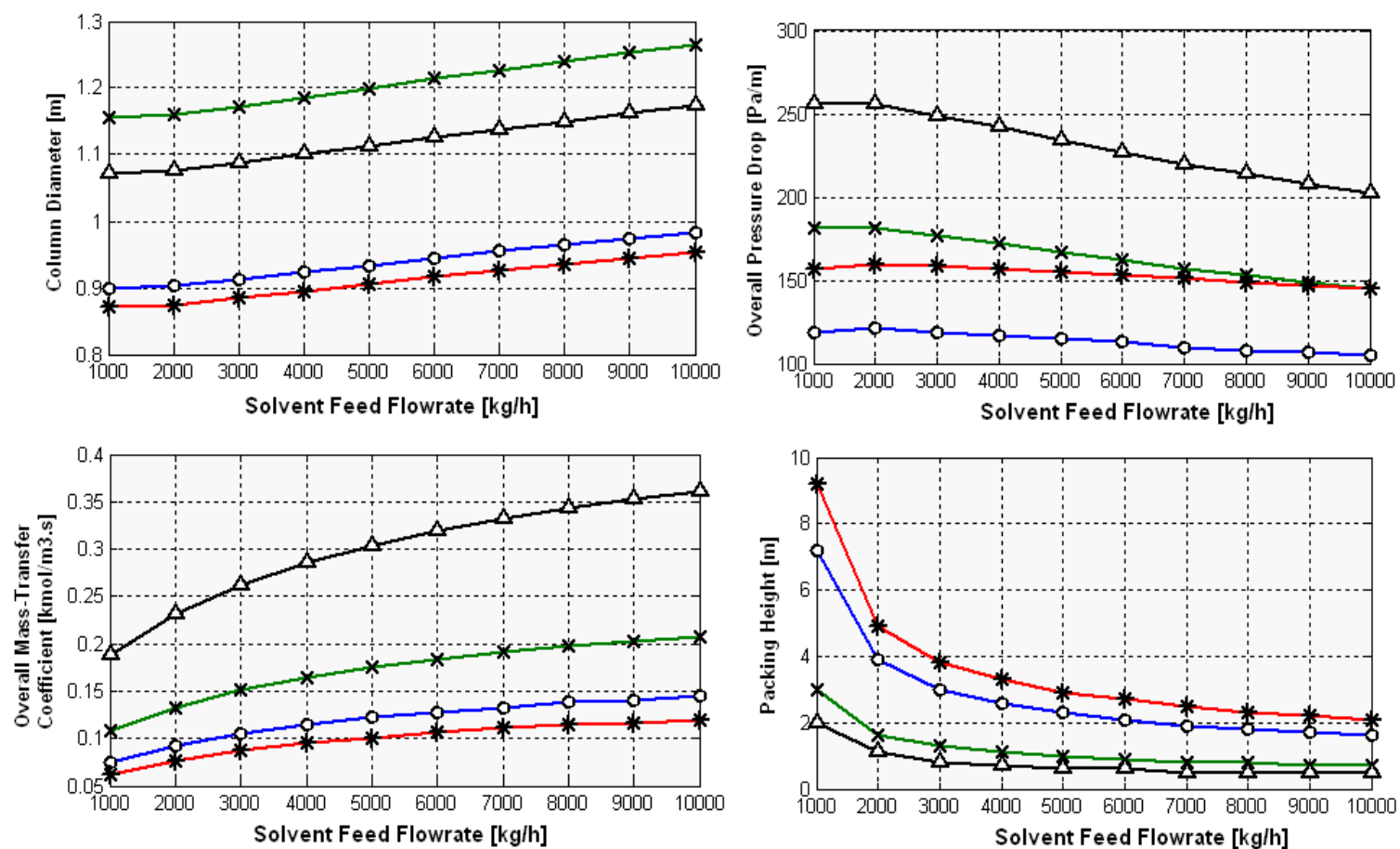

$\multimap-$ Hiflow $\rightarrow$ Pall $\rightarrow$ * Top-Pak $\triangle-$ VSP

Figure 9. Calculated Tower Diameter; Gas Pressure-Drop; Overall Mass-Transfer Coefficients and Packing Height values for the different packing types as a function of Solvent (Water) Feed Flowrate.
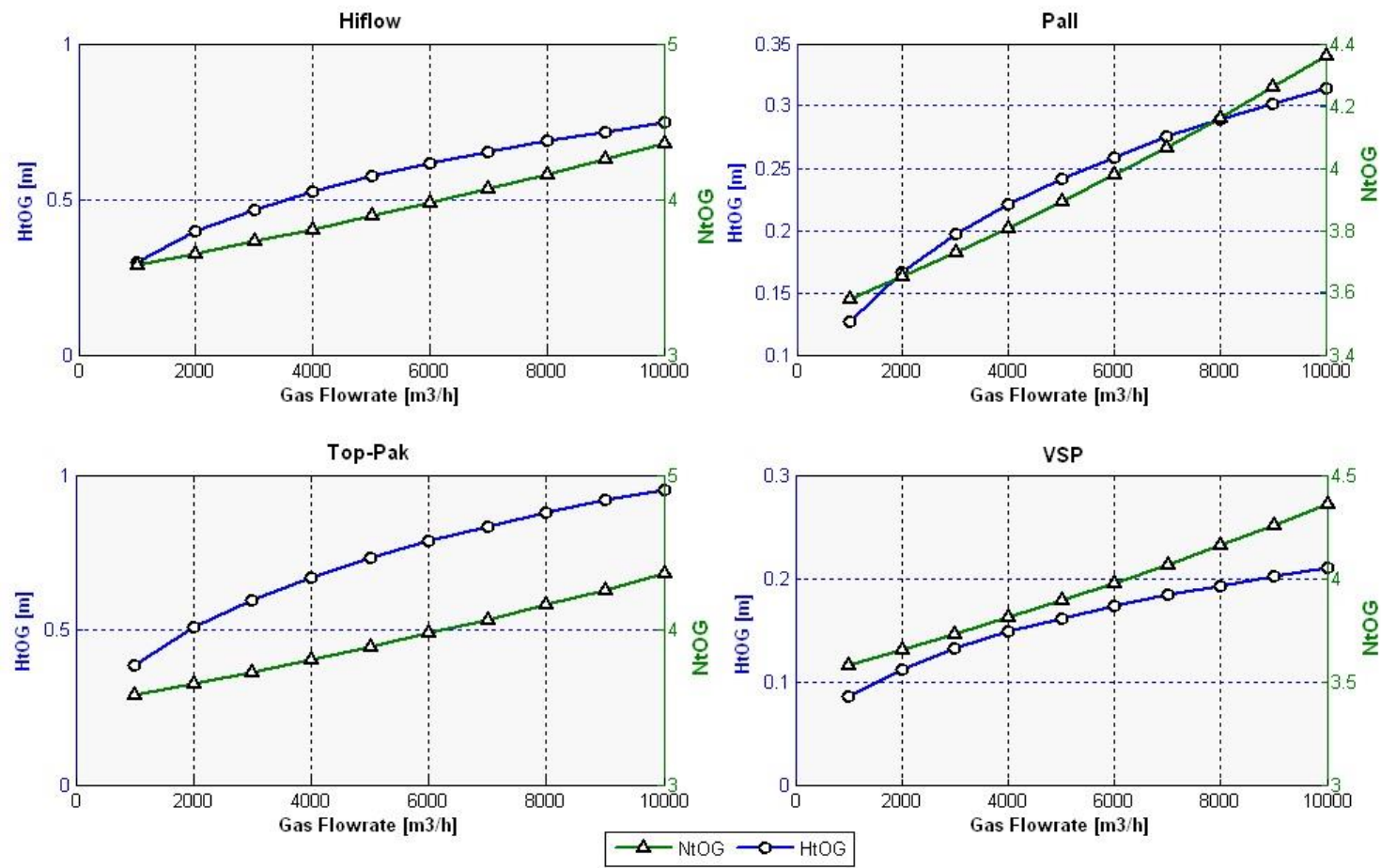

Figure 10. Calculated $\mathrm{HtOG}$ and $\mathrm{NtOG}$ values for each packing type as a function of Gas Mixture Feed Flowrate. 

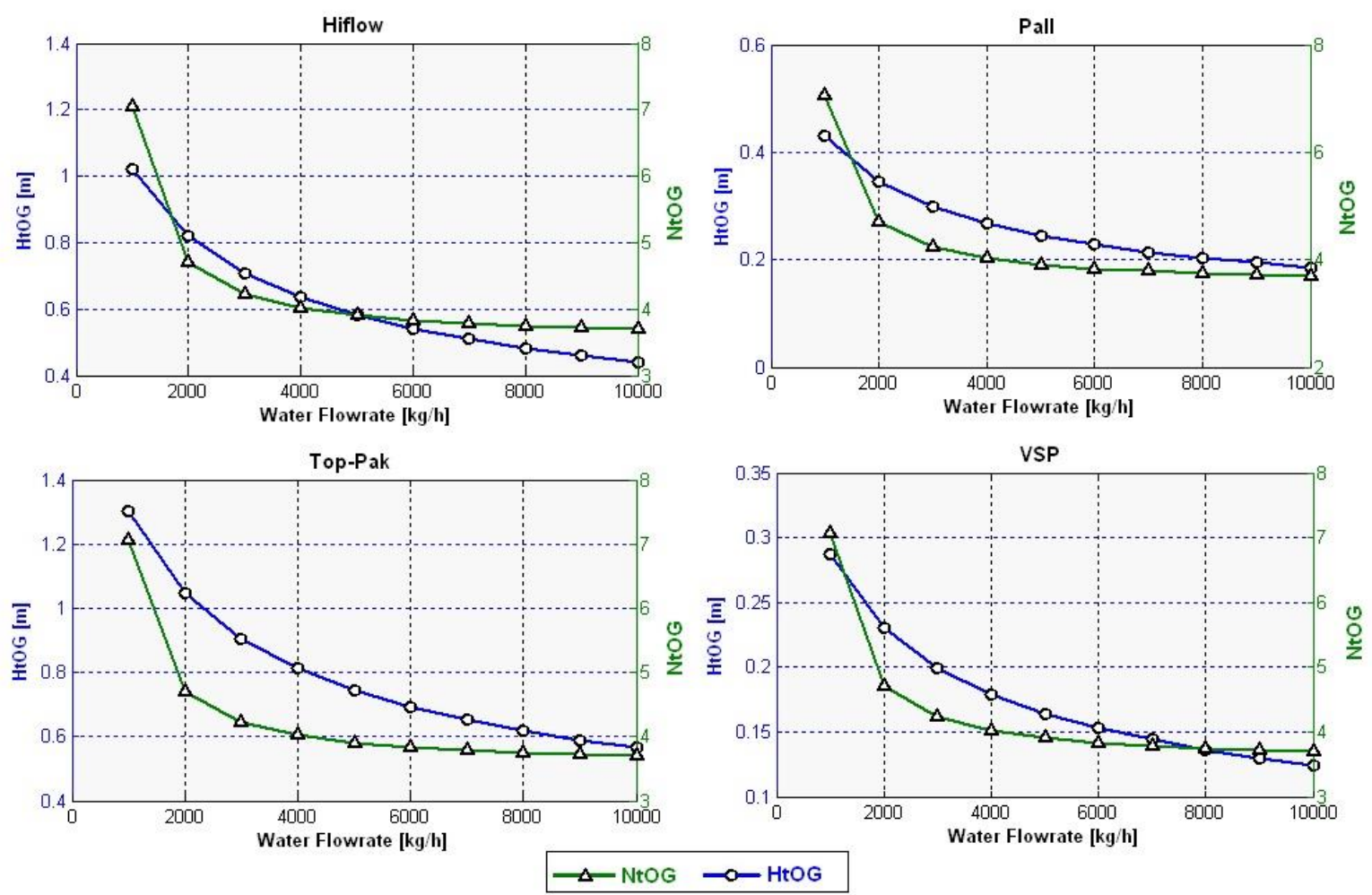

Figure 11. Calculated HtOG and NtOG values for each packing type as a function of Liquid Solvent (Water) Feed Flowrate.

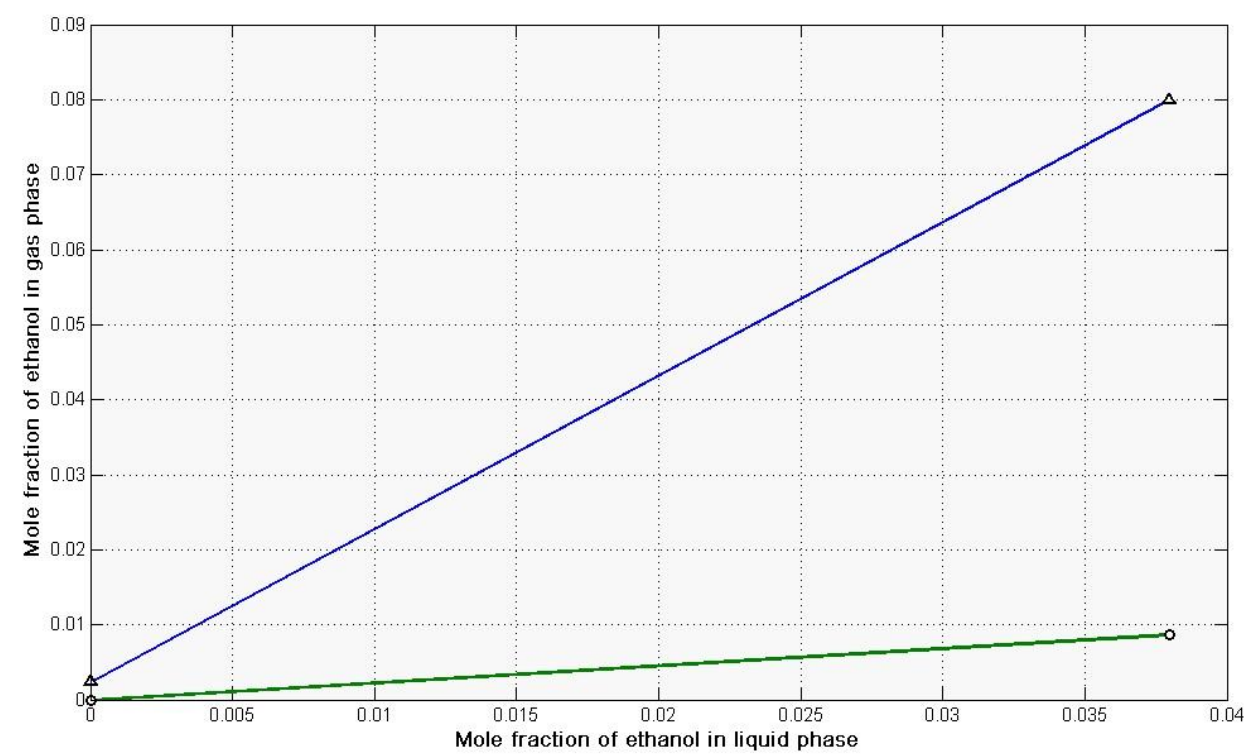

Figure 12. Operating and equilibrium lines for the absorption system

Figure 4 shows that the maximum result of packing height $(Z)$ is obtained if Top Pak ${ }^{\circledR}$ rings are employed $(2.60 \mathrm{~m})$, whereas the lowest value of $Z$ corresponded to $V S P^{\circledR}$ rings $(0.90 \mathrm{~m})$. Regarding tower diameter (D), Top $P a k^{\circledR}$ rings supplied the lowest value of $D(0.921 \mathrm{~m})$, while the $P a l l^{\circledR}$ rings had the highest value of $D$, with $1.221 \mathrm{~m}$. According to the correlations used during this work, the value to obtain of $D$ is 
directly related with the packing factor $(F p)$ value of each packing type, that is, if $F p$ increases so will increase the value of $D$.

As for the calculated values of gas pressure drop $(\Delta \mathrm{P} / \mathrm{Z})$ (Figure 5), the $V S P^{\circledR}$ rings exhibited the highest value of this parameter $(223 \mathrm{~Pa} / \mathrm{m})$, while the lowest value of this parameter corresponded to Hiflow $^{\circledR}$ rings, with $112 \mathrm{~Pa} / \mathrm{m}$. This variable depends on several factors, being the most important to consider (without taking into account the influence of the physical-chemical parameters of the fluids being handled) the gas mixture $\left(Q_{G}\right)$ and solvent $\left(m_{L}\right)$ feed flowrates, mass-transfer surface area per unit volume of packing (a); packing porosity ( $\varepsilon$ ), $F p$ and $D$. In general, $\Delta \mathrm{P} / \mathrm{Z}$ will increase if $a, m_{L}$ and $D$ decreases and if $\varepsilon, Q_{G}$ or $F p$ increases.

Finally, VSP ${ }^{\circledR}$ rings supplied the greater value of the overall volumetric mass-transfer coefficient $\left(K_{m}\right)$ (Figure 6) corresponding to $0.326 \mathrm{kmol} / \mathrm{m}^{3} \mathrm{~s}$, while the lowest value of this parameter belonged to Top $P a k^{\circledR}$ rings $\left(0.068 \mathrm{kmol} / \mathrm{m}^{3} \mathrm{~s}\right)$. The most influential variables on $K_{m}$ are the hydraulic factor $\mathrm{Ch}$ and the mass-transfer factor $\mathrm{C}_{\mathrm{V}}$; as well as $Q_{G}, m_{L}, F p, a, D$ and $\varepsilon$. In that case, the value of $K_{m}$ will increase with an increment of $\mathrm{Ch}, \mathrm{C}_{\mathrm{V}}$ and $a$, as well as with a reduction of $F p, D$ and $\varepsilon$. On the other hand, an increment of $Q_{G}$ and a reduction of $m_{L}$ will decrease the value of $K_{m}$ for the four packing types evaluated, according to the results showed in Figure 8 and Figure 9.

Regarding to the results showed in Figure 8, an increment of the $Q_{G}$ (maintaining constant the value of $m_{L}$ ) will increase the value of D, $\Delta \mathrm{P} / \mathrm{Z}$ and $Z$, while $K_{m}$ will decreases. On the other hand, an increment of the $m_{L}$ (keeping constant the value of $Q_{G}$ ) will increase the values of $D$ and $K_{m}$, while both $\Delta \mathrm{P} / \mathrm{Z}$ and $Z$ decrease for the four packing types.

As for the results displayed in Figure 10, an increment of $Q_{G}$ will increase both the overall height of a gasphase transfer unit $\left(H_{t O G}\right)$ and the overall number of gas-phase transfer units $\left(N_{t O G}\right)$ for all the four packing types evaluated. In contrast, the Figure 11 showed the opposite pattern, that is, both the $H_{t O G}$ and $N_{t O G}$ decrease with an increment of the water feed flowrate. The results obtained in both figures mean that both the eight of the apparatus required to accomplish the requested separation and the number of theoretical stages required to carry out the same separation in a plate-type apparatus will increase if $Q_{G}$ increases ( $m_{L}$ constant), and will decrease if $m_{L}$ increases $\left(Q_{G}\right.$ constant).

Analyzing and summarizing the results showed in Table 9, the Pall rings supplied the highest value of $D$ $(1.221 \mathrm{~m})$, while Hiflow $^{\circledR}$ rings provided the lowest value of $\Delta P / Z(112 \mathrm{~Pa} / \mathrm{m})$. On the other hand, Top $P a k^{\circledR}$ rings presented the highest values of both $H_{t O G}(0.671 \mathrm{~m})$ and $\mathrm{Z}(2.60 \mathrm{~m})$, as well as the lowest values of $D(0.921 \mathrm{~m}), K_{m}\left(0.109 \mathrm{kmol} / \mathrm{m}^{3} . \mathrm{s}\right)$ and $a_{\mathrm{h}}\left(55.66 \mathrm{~m}^{-1}\right)$. Finally, $V S P^{\circledR}$ rings had the highest values of $\Delta \mathrm{P} / \mathrm{Z}(223 \mathrm{~Pa} / \mathrm{m}), K_{m}\left(0.326 \mathrm{kmol} / \mathrm{m}^{3} . \mathrm{s}\right)$ and $a_{\mathrm{h}}\left(169.57 \mathrm{~m}^{-1}\right)$, and the lowest values of both $H_{t O G}$ $(0.148 \mathrm{~m})$ and $Z(0.60 \mathrm{~m})$. It should be noted that the value of $D$ obtained for $V S P^{\circledR}$ rings, which is the second highest value of $D$ of all the packing types considered, is only $18.6 \%$ higher than the lowest value of $D$ obtained, corresponding to Top Pak ${ }^{\circledR}$ rings $(0.921 \mathrm{~m})$.

Considering the results obtained for the four packing types evaluated, it can be concluded that the most appropriate packing to use for this service or application is the $V S P^{\circledR}$ rings, since it supply the most economic geometrical results and the highest mass-transfer conditions.

\section{CONCLUSIONS}

The Pall $^{\circledR}$ rings provided the greatest value of tower diameter $(D)[1.221 \mathrm{~m}]$. The Hiflow ${ }^{\circledR}$ rings supplied the lowest value of the overall pressure $\operatorname{drop}(\Delta P / Z)[112 \mathrm{~Pa} / \mathrm{m}]$.

The Top Pak ${ }^{\circledR}$ rings presented the lowest values of $D[0.921 \mathrm{~m}]$, the volumetric gas-phase mass-transfer coefficient $\left(K_{v G}\right)\left[0.116 \mathrm{kmol} / \mathrm{m}^{3} . \mathrm{s}\right]$, the volumetric liquid-phase mass-transfer coefficient $\left(K_{v L}\right)[0.372$ $\left.\mathrm{kmol} / \mathrm{m}^{3} . \mathrm{s}\right]$, the overall convective mass-transfer coefficient $\left(K_{m}\right)\left[0.109 \mathrm{kmol} / \mathrm{m}^{3} . \mathrm{s}\right]$, and the effective specific surface area of packing $\left(a_{\mathrm{h}}\right)\left[55.66 \mathrm{~m}^{-1}\right]$; as well as the greatest values of the overall height of a gas-phase transfer unit $\left(H_{t O G}\right)[0.671 \mathrm{~m}]$ and packing height $(Z)[2.60 \mathrm{~m}]$.

Nexo Revista Científica / Vol. 29, No. 02, pp. 83-104 / Diciembre 2016 
The $V S P^{\circledR}$ rings presented the highest values of $\Delta P / Z[223 \mathrm{~Pa} / \mathrm{m}], K_{v L}\left[1.172 \mathrm{kmol} / \mathrm{m}^{3} . \mathrm{s}\right], K_{v G}[0.349$ $\left.\mathrm{kmol} / \mathrm{m}^{3} . \mathrm{s}\right], K_{m}\left[0.326 \mathrm{kmol} / \mathrm{m}^{3} . \mathrm{s}\right]$ and $a_{\mathrm{h}}\left[169.57 \mathrm{~m}^{-1}\right]$, as well as the lowest values of $H_{t o G}[0.148 \mathrm{~m}]$ and $\mathrm{Z}[0.6 \mathrm{~m}]$.

An increment of the gas mixture feed flowrate $\left(Q_{G}\right)$ (keeping constant $\left.m_{L}\right)$ increases the values of $D, \Delta P / Z$ and $Z$, while $K_{m}$ decreases for the four packing types considered. An increment of the solvent feed flowrate $\left(m_{L}\right)$ (maintaining constant $Q_{G}$ ) will increase the values of $D$ and $K_{m}$, while both $\triangle P / Z$ and $Z$ decreases for the four packing types evaluated. An increment of $Q_{G}$ will increase the values of both the $H_{t O G}$ and the overall number of gas-phase transfer units $\left(N_{t O G}\right)$ for the four packing types.

Both the $H_{t O G}$ and $N_{t O G}$ decrease with an increment of $m_{L}$. The most adequate packing to use on this absorption system is the $\boldsymbol{V S} \boldsymbol{P}^{\circledR}$ rings since it provided the highest mass-transfer conditions with the lowest column dimensions.

\section{REFERENCES}

1. Arwikar, K.J. (1981). Mass Transfer in Packed Column Absorption and Multicomponent Distillation, Ph. D Thesis. Santa Barbara, U.S.A: University of California.

2. Asano, K., (2006). Mass Transfer: From Fundamentals to Modern Industrial Applications. Weinheim, Germany: WILEY-VCH Verlag GmbH and Co. KGaA.

3. Asbjörnsson, G. (2013). Modelling and Simulation of Dynamic Behaviour in Crushing Plants, Thesis for the Degree of Licenciate of Engineering. Göteborg, Sweden: Chalmers University of Technology.

4. Benitez, J., (2009). Principles and modem applications of mass transfer operations, 2nd ed. Hoboken, U.S.A: John Wiley and Sons.

5. Billet, R. (1989). Packed Column Analysis and Design. Department of Thermal Separation Processes. Bochum, Germany: Ruhr-Universität.

6. Boyadjiev, C. (2010). Theoretical Chemical Engineering: Modeling and Simulation. Berlin, Germany: Springer-Verlag.

7. Bravo, J. L., \& Fair, J. R. (1982). Generalized Correlation for Mass Transfer in Packed Columns. Ind. Chem. Eng. Process. Des. Dev., 21, 162-170.

8. Brunazzi, E., Nardini, G., \& Paglianti, A. (2002). An Economical Criterion for Packed Absorption Column Design. Chem. Biochem. Eng. Q., 15, 199-206.

9. Coker, A. K. (1991). Understanding the Basics of Packed-Column Design. Chemical Engineering Progress, November 1991, 93-99.

10. Dimian, A. C., \& Bildea, C. S. (2008). Chemical Process Design: Computer-Aided Case Studies. Weinheim, Germany: WILEY-VCH Verlag GmbH and Co. KGaA.

11. Fair, J. R., \& Bravo, J. L. (1987). Prediction of Mass Transfer Efficiencies and Pressure Drop for Structured Tower Packings in Vapor/Liquid Service. I. Chem. E. Symp. Ser., 104, 183-201.

12. Finlayson, B. A. (2006). Introduction to chemical engineering computing. Hoboken, U.S.A: John Wiley and Sons.

13. González-Bustamante, J. A., Sala, J. M., López-González, L. M., Míguez, J. L., \& Flores, I. (2007). Modelling and dynamic simulation of processes with 'MATLAB'. An application of a natural gas installation in a power plant. Energy, 32, 1271-1282.

14. Karris, S. T. (2004). Numerical Analysis Using MATLAB ${ }^{\circledR}$ and Spreadsheets, 2nd ed. Fremont, U.S.A.: Orchard Publications.

15. Kleine, O. (1998). Calculation and Design of Packed Distillation Column. M.Sc. Thesis, Finland: Lappeenranta University of Technology.

16. Kukurugya, J., \& Terpák, J. (2006). Simulation Models of Processes from the Area of Raw Materials Processing Created in MATLAB-SIMULINK ${ }^{\circledR}$. Slovak Republic: Institute of Control and Informatization of Production Processes Kosice, Technical University of Kosice.

17. Leye, L. D., \& Froment, G. F. (1986). Rigorous Simulation and Design of Columns for Gas Absorption and Chemical Reaction II. Computers and Chemical Engineering, 10, 493-504.

Nexo Revista Científica / Vol. 29, No. 02, pp. 83-104 / Diciembre 2016 
18. Lockett, M. J. (1998). Easily Predict Structured-Packing HETP. Chem. Eng. Prog., January 1998, 60-66.

19. Ludwig, E. E. (1997). Applied process design for chemical and petrochemical plants, 3rd ed., Oxford, U.K: Butterworth-Heinemann.

20. Marcilla, A. (1999). Introducción a las Operaciones de Separación. Tema 3: Absorción. Alicante, España: Espagrafic.

21. Matos, R., \& Hing, R. (1990). Aspectos fundamentales de la química-física. Ciudad de la Habana, Cuba: Editorial Pueblo y Educación,.

22. McNutly, K., \& Chopey, N. (1994). Effective design for absorbtion and stripping. Chemical Engineering, 101, 43-49.

23. Mohamadbigy, K., Bazmi, M., Behradi, R., \& Binesh, R. (2005). Amine Absorption Column Design Using Mass Transfer Rate Simulation. Petroleum and Coal, 47, 39-46.

24. Mušič, G., \& Matko, D. (1998). Simulation support for recipe driven process operation. Computers Chem. Engng., 22, 887-890.

25. Nakamura, S. (2002). Numerical Analysis and Graphic Visualization with MATLAB, 2nd ed. Upper Saddle River, U.K.: Prentice-Hall,.

26. Olutoye, M. A., \& Mohammed, A. (October 2006). Modelling of a Gas-Absorption Packed Column for Carbon Dioxide-Sodium Hydroxide System. AU J.T., 10, 132-140.

27. Pavlov, K. F., Romankov, P. G., \& Noskov, A. A. (1981). Problemas y ejemplos para el curso de operaciones básicas y aparatos en tecnologia química. Moscú: Editorial Mir.

28. Perry, R. H., \& Chilton, C. H. (2008). Perry's Chemical Engineers' Handbook, 8th ed. New York, U.S.A.: McGraw-Hill Book Co.

29. Peters, M. S., \& Timmerhaus, K. D. (1991). Plant design and economics for chemical engineers, New York, U.S.A.: McGraw-Hill Book Co.

30. R. Billet, and Schultes, M. (1995). Packed Towers in Processing and Environmental Technology. New York, U.S.A.: VCH.

31. Rahbar, M. S., \& Kaghazchi, T. (2005). Modeling of packed absorption tower for volatile organic compounds emission control. Int. J. Environ. Sci. Tech., 2, 207-215.

32. Richardson, J. F., \& Harker, J. H. (2002). Coulson and Richardson's Chemical Engineering: Particle Technology and Separation Processes, 5th ed. Oxford, U.K.: Butterworth-Heinemann,.

33. Rogers, T. N., Zei, D. A., Rowley, R. L., Wilding, W. V., Oscarson, J. L., Yang, Y. \& Danner, R. P. (2007). DIPPR ${ }^{\circledR}$ Data Compilation of Pure Chemical Properties, New York, U.S.A.: Design Institute for Physical Properties, AIChE.

34. Sherwood, T. K., \& Pigford, R. L. (1952). Absorption and Extraction. New York, U.S.A.: McGraw-Hill Book Company.

35. Shulman, L. H., \& Margolis, E. D. (2004). Performance of packed column (IV): Effect of gas properties, temperature and pressure in gas-phase mass transfer coefficient. AIChE. J., 31, 157161.

36. Siegler, H. (2003). Diseño de un Módulo para el Dimensionamiento Hidráulico de Torres Empacadas. Bogotá, Colombia: Universidad Nacional de Colombia.

37. Strigle, R. F. (1987). Random Packings and Packed Towers: Design and Applications. Houston, U.S.A.: Gulf Publishing Company.

38. The Math Works, I. (2009). MATLAB ${ }^{\circledR}$ [Version 7.8.0.347 (R2009a)]: The Math Works, Inc. www.mathworks.com

39. Treybal, R. E. (1980). Mass Transfer Operations, 3rd ed. New York, U.S.A.: McGraw-Hill Book Company.

40. Wagner, I., Stichlmair, J., \& Fair, J. R. (1997). Mass Transfer in Beds of Modern, High Efficiency Random Packings. Ind. Eng. Chem. Res., 36, 227-237.

41. Yang, W. Y., Cao, W., Chung, T. S., \& Morris, J. (2005). Applied numerical methods using MATLAB $^{\circledR}$. Hoboken, John Wiley and Sons. 


\section{SEMBLANZA DE LOS AUTORES}

Amaury Pérez Sánchez: Obtuvo el grado de Ingeniero Químico en la Universidad de Camagüey "Ignacio Agramonte Loynaz", Cuba, donde actualmente es profesor instructor e investigador auxiliar. Trabaja en líneas de investigación relacionadas con la transferencia de calor y masa en plantas procesadoras de alimentos y biotecnológicas, además del empleo de simuladores de procesos para evaluar y/o diseñar procesos, sistemas u operaciones unitarias.

Eddy Javier Pérez Sánchez: Obtuvo el grado de Ingeniero Químico en la Universidad de Camagüey "Ignacio Agramonte Loynaz", Cuba. Actualmente labora en la Empresa Agroindustrial Cítricos Ceballos, donde es especialista principal del área de Producción. Trabaja en líneas de investigación relacionadas con el diseño, evaluación y optimización de sistemas y procesos de la industria alimenticia, específicamente la simulación de procesos empleando simuladores profesionales.

Rutdali Segura Silva: Obtuvo el grado de Ingeniero Químico en la Universidad de Camagüey "Ignacio Agramonte Loynaz", Cuba. Actualmente labora en el Centro de Ingeniería Genética y Biotecnología de Camagüey, donde es especialista del área de documentación. Trabaja en líneas de investigación vinculadas con la filtración estéril y formulación de vacunas oleosas, además del diseño y/o evaluación de procesos biotecnológicos y fermentativos. 